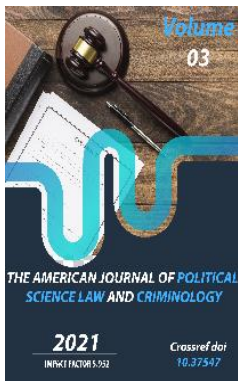

Copyright: Original content from this work may be used under the terms of the creative commons attributes 4.0 licence.

\section{The History Of Provenance Of Law-Defensive Institution In Uzbekistan}

Bakhtiyor Murodov

DSc, Associate Professor, Academy Of The Ministry Of Internal Affairs Of The Republic of Uzbekistan, Tashkent, Uzbekistan

\section{Sarvar Abdukahhorov}

Doctoral Researcher, Academy Of The Ministry Of Internal Affairs Of The Republic Of Uzbekistan, Tashkent, Uzbekistan

\title{
ABSTRACT
}

The article considers the emergence and phases of development of the law-defensive institution from the history of the ancient world to the present day, as well as the contribution of our great ancestors to the more effective use of this institution is explored.

\section{KEYWORDS}

Law-defensive institution, sponsorship, attorney, law, reform, criminal process.

\section{INTRODUCTION}

The systematic affairs have been carried out to strengthen the organizational-legal framework for the protection of human rights, to implement the international human rights standards into national legislation system and fulfillment of international obligations, as well as works on human rights protection in the recent years [1]. 
It is perceptible that the main goal of the reforms being carried out in our country today is to protect the individual, to ensure his free and prosperous life. According to the philosopher, Lichtenberg, "It is necessary to consider whether is it possible to justify before condemning someone" [2].

Indeed, this idea is very relevant, and following to it can be the solution to many current problems in the sphere of forensicsinvestigation. In our view, we must study its history first, namely, its provenance in order to fully understand the essence of everything. The history cultivates us a lot of matters. Therefore, it is no coincidence that it is called the "great teacher". Everything has its own origin, or history. This rule is also relevant to the institution of protection in the criminal proceedings.

Advocate participates as defense counsel in the criminal process. Therefore, the history of the establishment of the institution of defense is inseparable from the history of the establishment of the advocacy.

The term "protection" in the explanatory dictionary of Uzbek language is expressed as: 1. Assistance, support, sponsorship; 2 . The acts of bias towards the accused, in the sense of the opinion expressed is the acquittal [3], the term "advocate" is taken from the Latin word «advocatus» which means that, someone who conducts in the court, a subject who carries out defence in the trial [4].

Secondly, advocacy was formerly known as a series of lawyers, that is, a group of individuals who have dedicated themselves to this profession [5]. The emergence of the institution of protection in law is directly related to the emergence of right in human being. There is no institution of protection without rights.

Turan in ancient period, Movarounnakhr in the Middle ages, later called Turkestan, Central Asia, Middle Asia was one of the first centers of human civilization in the region.

The system of crime and punishment in the ancient states of the Republic was regulated on the basis of customary law until the VI-V centuries $B C$ [6] and the main source of Zoroastrianism, the "Avesto", was the miracle created by our ancestors for the first time in the history of humanity. The ideas about national statehood, spirituality, and the protection of human rights emerged in the ancient Zoroastrian state, too [8].

The tribes were participated as a victim of the crime if we look back to ancient times [9]. This idea leads us to the conclusion that in ancient times an entire tribe participated in the trial on behalf of one person, and that this custom was the first manifestation of family representation. With the development of the institution of defense, independent lawyers, who practiced law gradually began to emerge in ancient Greece (Athens) and Rome. Athenian lawyers prepared citizens to make speech in court or to speak with them simultaneously in court in ancient Greece. Their speeches were very coherent and fluent. Wellknown senator Cicero was the quintessence of orator in court at the time. Lawyers rewarded for their assistance, on behalf of money.

Ancient Roman lawyers (advocates) were open to all layers of society, and it was possible to stop them anywhere and even on the street and ask for their advice as an assistance. Working as an advocate was considered prestigious at that time, and many even 
emperors Caesar and Pompey instigated their careers with this profession.

The most ancient law institution, the development of the advocate profession in Uzbekistan, began with family representation, in which the head of the family defended the interests of each member of the family in court as in most countries of the world.

The kinship relationship was commonly developed in Germans, Czechs, Poles, Slovaks, Bulgarians, Serbs, Croats, Slovenes, Montenegrins, Macedonians, Bosnians, Russians, Ukrainians, and Belarusians in the middle ages.

The kings had the right to use their representatives in court proceedings in most countries of the world, in the middle ages. This privileged right was given only to kings and could not be exercised by other persons. In the middle ages churches also use their own representatives in the process of the court. Such representatives were chiefly selected from among the priests. The consent of the king was required for the vulnerable persons, i.e., women, minors, and the physically handicapped, who were unable to defend their rights independently, to assert their rights with the help of representatives. The person has the opportunity to hire another person who knows the law to protect his/her rights according to the agreement in case the king agrees that a helpless person has given this opportunity. The range of users of representatives in court expanded, and eventually the entire nation was enabled to exercise such right over the time. The time when each person is allowed to be represented in court is the time when the advocacy (institution of advocates) appears.
The plenty of lawyers (political zeal and savvy) appeared from our country during the Awakening epoch in Central Asia. They studied Islamic law (fiqh) and incentivized others to do the same, to protect their own and other people`s rights. Among such scholars were Ibn Sina, Beruni, Farobi, Ulugbek, Navoi, al-Bukhari and others. The foremost scholar among them, Burkhanuddin al-Marghinani with his great masterpiece "Khidoya" (the right way) made a valuable great contribution to today's Muslim jurisprudence.

Extensive attention was paid to the protection of human rights, protection of man, respect for someone's dignity even during the reign of the Timurids dynasty. It is obvious that man, his/her dignity, honor and freedom were the highest values at that time comparing the "Temur's rules", which is regarded as the legal source of the Uzbek statehood, with the abovementioned documents.

Many lawyers and philosophers have expressed their views and opinions on the human rights in the later stages of development [10].

In addition to conducting judicial proceedings, Kazikalon (in fact, the chairman of the Supreme Court in present days) supervised the protection of the rights of the bereaved and widows in the Emirate of Bukhara, in the middle ages. Medieval judges are distinguished by the presence of special servants, scientists of Muslim law - muftis (according to the Islamic religion, the Mufti is the highest rank and someone who controls all the other relevant Islamic leaders) and scholars, they made the narrative, namely, the model resolution of the dispute or an accusation according to Shariat law, on the instructions of the judge (ancient kazi), plaintiff, accuser, defendant or accused. 
For instance, 12 muftis served under the Chief Judge of the Emirate of Bukhara (Kazikalon), who provided pecuniary service to visitors, the complainant in the preparation of complaints and other practical records.

Changes in its judiciary since Russia invaded Central Asia had a direct impact on its colonies, including the Governor-Generalship of Turkestan, established in 1867. Therefore, it would be logically expedient to study the history of the development of the institution of protection in Uzbekistan and Russia in relation to each other simultaneously.

As a result of changes in the Occidental countries, Russia adopted the new Judicial Charter in 1864, which embodied the idea of regulating the relations of the individual, society and state on the basis of legal equality and mutual interest. The absolute independent advocacy based on the French model has emerged in Russia in accordance with this Charter. Consequently, 1864 was considered as the year of the emergence of professional advocacy in Russia.

All citizens of both genders, who have civil rights and have not tarnished their honor have the right to participate as the defense counsel in the courts in accordance with the Decree I of the Courts dated on November 24, 1917. The counsel of advocates and defendants in the civil proceedings was established under the executive committee of the Soviets in accordance with the Charter "On the Unique People's Court", adopted on November 30, 1918. The task of protection was assigned to government agencies from that time onwards. A person who participated as a defense counsel in one case was entitled to participate as a defendant in another case.
It can be observed that the rights of the individual are better protected in the Criminal procedural code (CPC) of the former Uzbek SSR adopted in 1959, than in the Criminal procedural code of the former Uzbek SSR in 1926.

This is because the defense attorney (advocate) could not take part in the preliminary investigation in the CPC of the Uzbek SSR, adopted in 1926.

Advocate had the right to meet with his client (the accused person) in the CPC adopted in 1959. However, the code did not stipulate that this meeting should take place separately (without attendance of third side). The defense counsel were also enabled with the right to review all the materials in the case, present evidence, appeal against the actions of the investigator, prosecutor and the court, and other rights according to the Article 46 of this CPC.

It should be highlighted that the Republic of Uzbekistan was one of the first after independence to adopt the new appropriate Code of criminal procedure on September 22, 1994, embodying democratic and humane ideas regulating criminal procedure, and to implement it on April 1, 1995. The advocate's ability to participate in the criminal proceedings has greatly expanded in this CPC.

The law "On advocacy" was adopted on December 27, 1996, and the law "On guarantees of Advocacy and social protection of advocates" was adopted in December 1998. 2 laws and more than 10 legal acts related to the institution of advocacy are systemized with the adoption of the Law "On Advocacy and the activity of advocate". In 1999, the rights of the advocate were expanded, and the lawyer now 
has the right to participate in the review of the case too. The Decree of the President of the Republic of Uzbekistan "On further reforming the advocacy institution in the Republic of Uzbekistan" was adopted on May 1, 2008.

The need to develop the institution of advocacy, increase the role of advocates in the criminal, civil, administrative and economic cases is indicated in the paragraph 2.6 of the Decree of the President of the Republic of Uzbekistan dated on February 7, 2017 № 4947 "The Strategy of actions on five priority areas of development of the Republic of Uzbekistan in 2017-2021". The procedure for obtaining separate licenses for civil, criminal and economic cases introduced in accordance with the Decree of the President of the Republic of Uzbekistan dated on May 12, 2018 № 5441 “On measures to radically increase the efficiency of the advocacy institution and expand the independence of advocates". New procedure that the staff of operational-investigative organs shall obtain an application, explanation or testimony from the suspect, accused or defendant with the written permission of the interrogator, investigator, prosecutor or judge and only in the presence of the advocate (except in cases of dismissal of the advocate in the prescribed manner) in order to ensure reliable protection of the rights of the person from the moment of detection of the offense was introduced.

The badge "For the protection of human rights" was established in connection to the Decree of the President of the Republic of Uzbekistan "On approval of the National strategy of the Republic of Uzbekistan on human rights".

Uzbekistan was elected to the UN Human Rights Council for the first time in its history for the three-year term - 2021-2023 in the elections to the UN General Assembly on October 13, 2020. It should be emphasized that it is an international recognition of the fact that 169 out of 191 UN member states voted for our country, shows human rights are highly protected at the national level in our country.

\section{REFERENCES}

1. Decree of the President of the Republic of Uzbekistan dated on June 22, 2020, "On approval of the national strategy of the Republic of Uzbekistan on Human rights" //https://lex.uz/docs/4872355.

2. Landscapes of reality. 96 classic philosophers / Destinies, sayings, aphorisms. - T., 2013. P. 335.

3. Explanatory dictionary of Uzbek language. Under the editorship of A. Madvaliyev. The letter «M»., T - 2008, P. 531.

4. Zokirova U. A. The status of advocate in the Republic of Uzbekistan. Textbook. T., 2017.

5. A. T. Allamuratov. Advocacy in the Republic of Uzbekistan. Textbook. -T.: Publication house of TSLI, 2006. P. 11.

6. Theology. Islamic law: Manual / A. R. Rakhmanov, A. B. Narbekov, M. A. Turaev; responsible editor: N. P. Azizov, doctor of law sciences. - T, 2019. P. 149.

7. Saidakhmedov I. The history of state and law. - T., 2006. - P.74.

8. Sattarov A. Kh. The theory of human rights and the topical issues of protecting human rights in the activities of the internal affairs organs. Doctoral thesis of law sciences. - T., 2003.

9. Turayeva D. R. Improving the protective mechanisms of the victim's rights and interests in the criminal proceedings. 
Doi: https://doi.org/10.37547/tajpslc/Volume03Issue03-07

Doctoral thesis for law sciences. T., 2020.

P.17.

10. Mukhammadzhonov A. Timur and

Timurid's sultanate. - T.: General

Publication house "Laws". 1996. P. 127;

Timur`s rules. T.; Gafur Gulom. 1996. P.

343.; Karen L., Saidov A. Amir Timur and

France. T.: Justice. 1996. P. 84.

11. The Charter of criminal procedure [esource]: from November 20, 1864. URL:http:www.gumer.info/bibleotek_Bur s/History/Artikle/ust_ugprav.php (Date of application is April 09, 2019). 